\title{
王右丞集卷之八 近體詩
}

\section{1}

送封太守

忽解羊頭削，

仰馳熊軾轓。

揚舲發夏口，

4 按節向吴門。

帆映丹陽郭,

楓攢赤岸村。

百城多候吏,

8 露冕一何尊。 


\section{Juan 8: Recent style poems}

\section{1}

\section{Seeing off Governor Feng}

At once you untie your sheep-head dagger, ${ }^{1}$

And will hasten your carriage with its bear-shaped crossbar. ${ }^{2}$

Your barque will spread its sails and set forth from Xiakou,

4 Then you will halt your whip at Wumen.

Your sails will stand out against the city walls of Danyang,

And maple trees will cluster at the Redbank villages. ${ }^{3}$

So many clerks are waiting for you in your hundred towns; ${ }^{4}$

8 And how honored will you be as you display your ceremonial cap! ${ }^{5}$

1 "Sheep head": describes a triangular-shaped blade. This suggests that Feng is leaving a military office to take up the civil office of governor.

2 In Han times, the carriages of nobility were ornamented with a crossbar in the shape of a crouching bear. Consequently, in medieval writing "bear-shaped crossbar" became a metonymic expression for a regional governor.

3 Xiakou: At Wuchang, in the central Yangtze valley. Wumen: Another name for Suzhou. Danyang and Redbank are both located along the lower Jiang valley. Wang Wei is describing Feng's journey to his post in these couplets, both by water and by land.

4 See note to 4.3.8.

5 Emperor Ming of the Han was so impressed by the good administration of Guo $\mathrm{He}$ 郭賀, he rewarded him with a ceremonial robe and ornamental cap and commanded that he wear it in public so that the common people could see this recognition of his virtue. 


\section{2}

送嚴秀才還蜀

歩親為令子，

似舅即賢甥。

別路經花縣,

4 還鄉入錦城。

山臨青塞斷,

江向白雲平。

獻賦何時至,

8 明君憶長卿。

\section{3}

\section{送張判官赴河西}

單車會出塞,

報國敢邀勳。

見逐張征虜,

4 今思霍冠軍。

1 A reference to He Wuji 何無忌, who joined Liu Yu’s 劉裕 revolt against Huan Xuan 桓玄 at the end of the Eastern Jin dynasty. Huan Xuan remarked that $\mathrm{He}$ was a formidable foe because he was just like his uncle Liu Laozhi 牢之.

2 A poetic reference to Heyang County in Henan. Pan Yue once served as magistrate there and planted a large number of peach and plum trees, so that the county earned this nickname. 


\section{2}

Seeing off Flourishing Talent Yan on his return to Shu

Soothing one's parents is the mark of a fine son;

Just like your uncle, a worthy nephew. ${ }^{1}$

The road you take in parting will pass through Flower County; ${ }^{2}$

4 In returning home you'll enter Brocade City. ${ }^{3}$

Hills break off at the edge of the green pass;

The river is level as it stretches to white clouds.

When will the rhapsody you submitted to the court arrive?

8 Then an enlightened lord will think of Changqing. ${ }^{4}$

\section{3}

Seeing off Administrative Assistant Zhang on his way to $\mathrm{Hexi}^{5}$

Your single carriage will surely head out the pass;

You'll repay the country - not daring to focus on your own achievements.

Presently you'll follow after Zhang Attack-the-Caitiffs;

4 Now you're thinking about Huo the army leader. ${ }^{6}$

3 Abbreviation for Brocade Official City (just south of Chengdu), so called because the official in charge of overseeing the brocade industry had his headquarters there.

4 See note to 2.24.4.

5 The headquarters of the military commissioner, located in Liangzhou (Gansu). Qizhou was southeast of Chang'an, in southern Shaanxi.

6 Zhang Fei 張夏 of Shu received the title of "attacking the catiffs general." The Han general Huo Qubing was enfeoffed as the "army leading marquis." 
沙平連白雪, 蓬卷入黄雲。 慷慨倚長劍,

8 高歌一送君。

\section{4}

送岐州源長史歸（源與余同在崔常侍幕中 時常侍已沒)

握手一相送, 心悲安可論。 秋風正萧索,

4 客散孟嘗門。 故驛通槐里, 長亭下槿原。 征西舊旌節, 8 從此向河源。 
The sand is level, it stretches to the white snow;

The tumbleweed pulls up its roots and enters the brown clouds.

Full of valor, you lean on your long sword,

8 While a lofty song sees you off.

\section{4}

Seeing off Administrator Yuan of Qizhou on his way home (Yuan and I both served in the retinue of Attendant-in-Ordinary Cui; at this time, the Attendant had already passed away) ${ }^{1}$

We clasp hands, as we see each other off;

Our hearts grieve, but how can we discuss it?

The autumn wind just now blows desolate;

4 And guests scatter at the gate of the Lord of Mengchang. ${ }^{2}$ The old post station connects with Sophora Village;

The guest house sits below Althea Plain County. ${ }^{3}$

The old pennants and insignia of the western campaigns

8 From now on will head toward the source of the Yellow River. ${ }^{4}$

1 Cui Xiyi was Wang Wei's superior in the frontier district of Hexi from 737 until Cui's untimely death the following year.

2 A nobleman from the state of Qi during the Warring States era famous for patronizing talented men and taking in retainers. This refers to the departure of Cui Xiyi's staff after his death.

3 Locations through which Yuan will pass on his way home from Hexi.

4 This perhaps suggests that after Cui Xiyi's death the region will become unstable and break out in warfare. 


\section{5}

送張道士歸山

先生何處去,

王屋訪毛君。

別婦留丹訣,

4 驅雞入白雲。

人間若剩住,

天上復離群。

當作遼城鶴,

8 仙歌使爾聞。

\section{6}

\section{同崔興宗送衡岳瑗公南歸}

言從石菌閣，

新下穆陵關。

獨向池陽去,

4 白雲留故山。

1 King's House Mountain: in Shanxi, near Yangcheng 陽城. The Eastern Han Daoist Mao Bodao 毛伯道 cultivated the Way there and achieved immortality.

2 The Daoist Xu Mai 許邁 after his parents died abandoned his wife and went off traveling among famous mountains; it was believed that he later attained immortality.

3 See note to 1.5 .9 . 


\section{5}

Seeing off Daoist Master Zhang on his return to the hills

Master, to where are you departing?

You'll visit Lord Mao on King's House Mountain. ${ }^{1}$

You'll bid your wife farewell, keep the cinnabar secret, ${ }^{2}$

4 Driving your chickens before you, you'll enter white clouds. ${ }^{3}$

How can you live long in the human realm?

In heaven you'll part once more from the crowd.

You will become a heron at Liao city; ${ }^{4}$

8 You will get to hear the Transcendent's song.

\section{6}

Matching Cui Xingzong: "Seeing off Master Yuan of Heng

Marchmount on his return south" 5

From Stone Mushroom Lodge,

You recently descended on Muling Pass. ${ }^{6}$

Alone you left for Chiyang, ${ }^{7}$

4 Leaving white clouds behind on your former mountain.

4 The Transcendent Dingling Wei 丁令威 was from Liaodong in northeastern China. He transformed into a crane and flew to the city walls of his hometown, where he sang a song about becoming immortal and urging others to follow his path.

5 For the preface to this poem, see 19.9 below. The Heng was the southern of the five marchmounts, located in Hengzhou on the Xiang River (modern Hunan).

6 Stone Mushroom Lodge: one of the peaks of Mount Heng. Yuan would have to pass through Muling Pass in Hubei on the way to the capital.

7 A Han era name for a district in the capital region (Jingyang). 
綻衣秋日裹，

洗鉢古松間。

一施傳心法,

8 惟將戒定還。

\section{6a}

崔興宗：同王右丞送瑗公南歸

行苦神亦秀,

泠然溪上松。

銅瓶與竹杖,

4 來自祝融峰。

常願入靈获,

藏經訪遺踪。

南歸見長老,

8 且為說心胸。 
You patch your robe in the autumn sunlight, Wash your begging bowl under ancient pines.

Now that you've disseminated the Dharma of mind-transmission,

8 Nothing to do but return home with your precepts and meditation.

\section{6a}

Cui Xingzong: Matching Assistant Director of the Right Wang: "Seeing off Master Yuan on his return south"

In the pain of travel your spirit also prospers, Clear and cool, like a pine by a stream.

With your copper washing vase and bamboo staff

4 You come from Zhurong Peak. ${ }^{1}$

I've always hoped to go to the sacred marchmounts,

Store my classics away and go visiting historical sites.

When you return South and see the elder monks there

8 Tell them for me what my heart desires.

1 One of Heng's peaks. 


\section{7}

送銭少府還藍田

草色日向好,

桃源人去稀。

手持平子賦,

4 目送老萊衣。

每候山櫻發,

時同海燕歸。

今年寒食酒,

8 應得返柴屝。

\section{8}

錢起: 晚歸藍田酬王維給事贈別

卑棲却得性,

每與白雲歸。

1 See note to 2.22a.4.

2 Pingzi was the polite name for the Eastern Han poet Zhang Heng 張衡. When he became frustrated in office, he composed a "Rhapsody for Returning to the Fields." 


\section{7}

Seeing off District Defender Qian on his return to Lantian

The hues of the grass are finer daily;

And few people depart from my Peach Blossom Spring. ${ }^{1}$

With Pingzi's rhapsody held in my hand, ${ }^{2}$

4 My eyes bid farewell to Laolai dressed in his motley. ${ }^{3}$

You always wait for the mountain cherries to bloom, At times returning with the sea swallows.

This year when the Cold Food ale is ready ${ }^{4}$

8 You should be able to return to your scrap-wood door.

\section{8}

Qian Qi: Returning to Lantian in the evening: replying to a poem Supervising Secretary Wang Wei presented to me on parting ${ }^{5}$

I find my nature, even though I live lowly;

I always go home with the white clouds.

3 When an old man of seventy, Master Laolai dressed in motley clothing and pretended to be a small child in order to comfort his still living parents. He was considered one of the paragons of filial piety. This line suggests that Qian is returning to Lantian to look after his parents.

4 See note to 4.7.7.

5 The Zhao Diancheng edition mistakenly attributes this poem to Wang Wei and places it here. This is Qian Qi's response to 8.7. 


\section{㿟祿仍懷橘,}

4 看山免採薇。

暮禽先去馬,

新月待開屝。

霄漢時回首,

8 知音青瑣闈。

\section{9}

送邱為往唐州

宛洛有風塺,

君行多苦辛。

四愁連漢水,

4 百口寄隨人。

槐色陰清畫,

楊花惹暮春。

朝端肯相送,

8 天子紼衣臣。

1 When Lu Ji 陸績 visited Yuan Shu 袁衍 at the age of six in the company of his father, he took three oranges away with him hidden in the folds of his gown. $\mathrm{He}$ was discovered and he confessed he was taking them home for his mother. Here it refers to Qian Qi's desire to be filial. 
In search of salary, I still harbored oranges; ${ }^{1}$

4 I viewed the hills, avoided picking bracken. ${ }^{2}$

Evening birds fly before my departing horse, The new moon waits for me to open the door.

Sometimes I turn my head towards the Starry River,

8 Toward my intimate friend within the blue chain-patterned gates. ${ }^{3}$

\section{9}

Seeing Qiu Wei off to Tangzhou ${ }^{4}$

There is windblown dust over Wan and Luo;

There will be much hardship for you on your way.

Your "Four Griefs" will stretch to Han waters; 5

4 Your hundred mouths entrusted to people in Sui. ${ }^{6}$

Sophora tree hues shade the clear daytime;

Willow catkins tug at you in the late spring.

The highest in court are willing to see you off:

8 One of the emperor's ministers in his embroidered robe.

2 See note to 2.22.6. Qian is suggesting he was willing to serve, though wished to live as a recluse.

3 Qian Qi is gazing toward the capital and thinking of Wang Wei in his palace post. "Starry River" here is a poetic substitution for the palace. Palace gates and doors were painted with a chain-link pattern.

4 About 270 kilometers south of Luoyang.

5 "Four Griefs" is a cycle of poems attributed to the Han poet Zhang Heng when he was depressed over his lack of success. Wang is suggesting that Qiu Wei will compose his own "Four Griefs" in his new surroundings.

6 "Hundred mouths" is idiomatic for all the people of an extended household. Qiu has entrusted them to connections in Suizhou in Hubei (about 150 kilometers north-northeast of Wuhan). 


\subsection{0}

送元中丞轉運江淮

薄稅歸天府，

輕徭賴使臣。

擎沾賜帛老，

4 恩及卷綃人。

去問珠官俗，

來經石劫春。

東南御亭上，

8 莫使有風塵。

\subsection{1}

送崔九興宗游蜀

送君從此去,

轉覺故人稀。

徒御猶回首,

4 田園方掩屝。

1 Tax collection on transported goods was one of the tasks of the Transport Commissioner, as well as drafting labor.

2 Literally, "soak," "permeate." Government policy sometimes granted gifts of silk to the aged.

3 Said to be one of the customs of mermen. Compare 7.36.8 and note. 


\subsection{0}

Seeing off Yuan, Vice Censor-in-Chief and Transport

Commissioner, to the Jiang and Huai

Scant taxes are given back to the imperial storehouses;

The emissary takes responsibility for light corvée duties. ${ }^{1}$

Your delight will come to the elders presented with silk; ${ }^{2}$

4 Your benevolence will reach to the men rolling bolts of raw gauze. ${ }^{3}$

You will go off to ask about the customs of Pearl Office County; ${ }^{4}$

And will come back again during the spring of the anemone. ${ }^{5}$

To the southeast, above Yuting Station,

8 Don't let there be wind or dust. ${ }^{6}$

\subsection{1}

Seeing off Cui Nine Xingzong on his travels to Shu

I see you off - from now you depart;

I feel more and more that my friends grow few.

You drive on alone, yet still turn your head;

4 In fields and gardens I am shutting my door.

4 A prefecture in Guangxi (also known as Hepu) famous for its pearls. Wang is likely exaggerating the distance Yuan is going for poetic purposes (Pearl Office County was nowhere near the Jiang and Huai region).

5 It was believed that anemones (which were mistaken for flowers) "blossomed" in the spring (actually, feelers were mistaken for blossoms).

6 There were likely rebellions in the area at the time. These lines allude to a poem by the southern dynasties poet Yu Jianwu 座肩吾: “At Yuting I turn back to gaze / wind and dust, a thousand li of gloom." 
出門當旅食, 中路授寒衣。 江漢風流地,

8 游人何歲歸。

\subsection{2}

送崔興宗

已恨親皆遠, 誰憐友復稀。 君王未西顧,

4 游宦畫東歸。 塞迥山河淨, 天長雲樹微。 方向菊花節, 8 相待洛陽扉。 
Once you leave your gates, you'll be eating at inns;

You'll be sent winter clothes while still on the road.

The Jiang and Han valleys are scenic lands;

8 What year will the traveler return?

\subsection{2}

Seeing off Cui Xingzong

I already resent that all my kin are far away;

So who pities me that my friends are few as well?

The emperor has yet to turn back west to Chang'an,

4 And traveling officials are all heading east to him. ${ }^{1}$

The frontier is far, the hills and rivers pure;

The sky is long, cloudy trees faint.

Just in the festival of chrysanthemums, ${ }^{2}$

8 Wait for me at the door of your Luoyang house.

1 This poem was written when Xuanzong was residing at the subsidiary capital of Luoyang, while Wang Wei was in Chang'an (probably around 734).

2 The festival of the Double Ninth (ninth day of the ninth month). 


\subsection{3}

送平淡然判官

不識陽關路, 新從定遠侯。 黄雲㫁春色,

4 畫角起邊愁。 瀚海經年到, 交河出塞流。 須令外國使,

8 知飲月支頭。

\subsection{4}

送孫秀才

帝城風日好, 況復建平家。 玉枕隻文算,

4 金盤五色瓜。 山中沽魚酒, 松下飯胡麻。 莫厭田家苦,

8 歸期遠復賖。 


\subsection{3}

Seeing off Administrative Assistant Ping Danran

You don't recognize the road to Yang Pass,

Since you're just now following the Marquis of Pacifying the Remote. ${ }^{1}$ Brown clouds cut off the spring colors;

4 A painted horn gives rise to frontier grief.

It will take you a year to reach the Gobi;

The Yarkhoto River comes flowing from out of the frontier.

You must command the emissaries to foreign lands:

8 "Learn to drink from a Tokharian skull."

\subsection{4}

Seeing off Flourishing Talent Sun

Scenery is fine in the imperial city,

Even more so at Jianping's house. ${ }^{3}$

Jade pillows, paired-pattern bamboo mats,

4 Gold plates with rainbow melons.

In the hills they only sell weak Lu wine,

And eat sesame under the pines.

But don't despise the hardship of your home in the country;

8 My own time to return is distant and far away. ${ }^{4}$

1 The Yang Pass was in Gansu and led to points west. "Pacifying the Remote" was a title granted to the Eastern Han general Ban Chao 班超.

2 See note to 6.6.20.

3 Song (southern dynasties) Prince of Jianping (either Liu Hong 劉宏 or Liu Jingsu 劉景素), both patrons of scholars.

4 That is, Sun may regret that he must abandon the luxuries of city life by returning to his rural homestead, but at least he can go home, unlike the poet. 


\subsection{5}

送劉司直赴安西

絕域陽關道,

胡沙與塞塺。

三春時有雁,

4 萬里少行人。

首蓿隨天馬,

葡桃逐漢臣。

當令外國䁕,

8 不敢䍃和親。

\subsection{6}

送趙都督赴代州得青字

天官動將星，

漢地柳條青。

萬里鳴习斗,

4 三軍出井陘。

1 Headquarters of the Anxi military governor, in Xinjiang.

2 See note to 8.13.2.

3 This is flattering Liu, suggesting that he might accomplish the same sort of thing the Han emissary Zhang Qian 張弿 and the Han General Li Guangli managed to compel Ferghana to send tribute horses (see 6.6.8 and note), and to bring alfalfa and grapes for cultivation in China. 


\subsection{5}

Seeing off Rectifier Liu on his way to $\mathrm{Anxi}^{1}$

In a remote realm, the road to Yang Pass: ${ }^{2}$

Western sands and frontier dust.

Geese are seen throughout the spring,

4 But few travelers for ten thousand li.

Alfalfa came with the fine Ferghana horses;

And grapes followed after the Han minister. ${ }^{3}$

Just make those foreigners fear us,

8 So they dare not seek a marriage alliance! ${ }^{4}$

\subsection{6}

Seeing off Commander-in-Chief Zhao on his way to Daizhou;

I received the rhyme "qing" [green]

In the constellation of officials the Commander Star trembles; ${ }^{6}$

While down in Han lands the willow branches are green.

Over ten thousand li they sound their cookpot-clappers; ${ }^{7}$

4 The three armies have set out from Well Gorge. ${ }^{8}$

4 During the Han, the northern Xiongnu tribes were dealt with either through marriage alliances with the Chinese imperial house or through attempts at military conquest.

5 Daizhou: in northern Shanxi, about 150 kilometers north of Taiyuan.

6 An astrological omen of war.

7 Used to announce the night watches in military camps.

8 A frontier pass in Hebei. 
忘身鲛鳳關，

報國取龍庭。

豈學書生輩,

8 窗間老一經。

\subsection{7}

送方城韋明府

遙思葭菼際,

胗落楚人行。

高鳥長淮水,

4 平無故虽城。

使車聽雉乳,

縣鼓應雞鳴。

若見州從事,

8 無嫌手板迎。

1 Dragon Court (Longting) was a ritual center for the Xiongnu.

2 Fangcheng: county in Tangzhou prefecture; see note to 8.9. This was the heart of the old state of Chu.

3 Ying was the capital of the state of Chu.

4 Two allusions of good magistracy. Yuan An (Eastern Han) wondered why Lu Gong's district of Zhongmou 中牟 was spared a plague of insects and sent an emissary there to find out. The emissary was struck by the fact that a child would not take a pheasant because it was looking after her chicks. Yuan assumed that 
With no regard for himself he departs Phoenix Gate-tower;

To repay his country he'll capture Dragon Court. ${ }^{1}$

How could he imitate those bookish scholars,

8 Who grow old by the window with a single classic text?

\subsection{7}

Seeing off Magistrate Wei of Fangcheng ${ }^{2}$

I think of you far away, at the edge of reeds and rushes,

Where Chu travelers are few and far between.

High-flying birds above the long Huai waters;

4 A plain of scrub covers the old Ying City. ${ }^{3}$

The emissary hears the pheasant nurturing its chicks,

The district drums respond to the rooster's cry. ${ }^{4}$

If you meet the staff of the Prefect,

8 Don't demur to greet them with tally in hand. ${ }^{5}$

this air of benevolence came from $\mathrm{Lu}$, and that it prevented the insect plague from arriving. Deng You 鄧敒 (Jin dynasty) was such a good magistrate, the local people tried to prevent him from leaving. When they tried to block his boat, he was forced to stay until he could sneak out at night. This inspired a song: "Bang, they beat the fifth-watch drum, / When roosters cry at the brink of dawn. We pulled at Master Deng but couldn't keep him, / We push out Magistrate Xie but he won't leave."

5 The official tally was proof of office. The new magistrate would be expected to meet with the staff of his superior, the Prefect. 


\subsection{8}

送李員外賢郎

少年何處去,

負米上銅梁。

借問阿戎父,

4 知為童子郎。

魚箋請詩賦,

橦布作衣裳。

意莰扶衰病,

8 歸來幸可將。

\subsection{9}

送梓州李使君

萬壑樹參天,

千山響杜鵑。

山中一半雨,

4 樹杪百重泉。 


\subsection{8}

Seeing off the worthy son of Vice Director Li

Where are you off to, young man?

To carry rice up Mount Copper-bridge. ${ }^{1}$

I inquired about you, Rong, from your father;

4 And learned that you are a Gentleman Youth. ${ }^{2}$

They'll request poems and rhapsodies on fish-scale patterned paper, And they'll make your robes from the cotton-tree. ${ }^{3}$

The tear-grass herb helps those who are old and ill;

8 When you come back, please bring some with you!

\subsection{9}

Seeing off Prefect Li of Zizhou ${ }^{4}$

In a myriad ravines the trees are level with the sky;

A thousand hills echo with the cuckoo.

In these hills, after even a partial rain,

4 Hundred layers of streams come down from branch-tips.

1 Mount Copper-bridge is in Shu in Hezhou, evidently the home district of the young man. Confucius' disciple Zilu once claimed to have carried rice over a hundred $l i$ to his parents.

2 Ruan Ji was a contemporary of Wang Hun's 王渾, but felt much more at home with Hun's son Wang Rong 戎. Gentleman Youth (tongzi lang) was a title granted to youths in the Han-Wei period who showed a knowledge of the Confucian tradition.

3 Both famous products of Shu.

4 In Sichuan, about 100 kilometers northeast of Chengdu. 


\section{漢女輸橦布， \\ 巴人訟芋田。 \\ 文翁翻教授, \\ 8 不敢倚先賢。}

\subsection{0}

\section{送張五諲歸宣城}

五湖千萬里,

況復五湖西。

漁浦南陵郭,

4 人家春穀溪。

欲歸江永永,

未到草萎菨。

憶想蘭陵鎮,

8 可宜猿更啼。

1 Wen Weng was a Han-era magistrate in Shu who worked hard to improve living conditions and to change the local (non-standard, "barbarian") customs. The poet is suggesting that in spite of the oddness of local habits (cotton, taro fields), a talented and activist magistrate will be able to guide his people to a more enlightened way of life. Some interpret the last line as meaning, "Don't you dare imitate (unlike Wen Weng) those early worthies who pursued non-action as the best way to govern." 
The women of Han will pay with cotton cloth;

The people of $\mathrm{Ba}$ will litigate over taro fields.

In spite of all, Wen Weng bestowed his instructions;

8 Do you not dare to rely on this former worthy? ${ }^{1}$

\subsection{0}

Seeing off Zhang Yin Five on his return to Xuancheng ${ }^{2}$

A million li of the Five Lakes, And furthermore to the west of the Five Lakes. ${ }^{3}$

A fishing bank outside the city walls of Nanling,

4 Houses of people on Chungu stream.

As you're about to return, the Jiang is spreading its flood;

Before you arrive, the grass will be lush and thick.

I imagine you at Lanling Stronghold;

8 Is it right for the gibbons to continue their cries? ${ }^{4}$

2 See note to 3.19. This poem describes in detail Zhang's journey from the capital: South to the Han River, then southwards to the Jiang, and then to Nanling in Xuanzhou.

3 Five Lakes: Probably Taihu and adjoining lakes. Xuanzhou is about $70 \mathrm{~km}$ southwest of Taihu.

4 I.e., should the gibbons be crying and making you homesick? 


\subsection{1}

送友人南歸

萬里春應畫,

三江雁亦稀。

連天漢水廣,

4 孤客虽城歸。

鄖國稻苗秀,

楚人菰米肥。

懸知倚門望,

8 遙識老萊衣。

\subsection{2}

送賀遂員外外甥

南國有歸舟,

荆門泝上流。

荅茫葭荻外,

4 雲水與昭邱。

樯带城烏去,

江連暮雨愁。 


\subsection{1}

Seeing off a Friend on his return south

After a myriad li the spring should end,

With geese fewer by the Three Jiang. ${ }^{1}$

Stretching to the sky, the Han waters are broad;

4 A lone traveler returns to Ying city.

Rice sprouts ripen in the state of Yun; ${ }^{2}$

Wild rice fattens among the people of Chu.

I imagine your parents leaning on the gate and gazing, ${ }^{3}$

8 Recognizing Laolai's motley from afar. ${ }^{4}$

\subsection{2}

Seeing off Vice-Director He Sui's nephew

There is a returning boat in the southern lands;

At Jingmen it advances upstream. ${ }^{5}$

The green is vast beyond reeds and rushes,

4 Where cloud-hid waters join with Zhao Hill. ${ }^{6}$

The mast departs, carrying city crows;

The Jiang is bleak as it joins with the evening rain.

1 Possibly Baling (near Dongting Lake), where the Jiang, Fengjiang, and Xiangjiang meet.

2 A small Spring and Autumn era state destroyed by Chu. Located near the modern city of Wuhan.

3 From a Zhanguo ce anecdote, leaning on a gate refers to parents anxiously awaiting the return of their child.

4 See note to 8.7.4.

5 In the central Jiang valley.

6 Zhao Hill is the tomb mound of King Zhao of Chu. 
猿聲不可聽，

8 莫待楚山秋。

\subsection{3}

送楊長史赴果州

褒斜不容嗐，

之子去何之。

鳥道一千里,

4 猿啼十二時。

官橋祭酒客,

山木女郎祠。

別後同明月,

8 君應聽子規。

\subsection{4}

送邢桂州

鐃吹喧京口，

風波下洞庭。 
It is best not to hear the cries of the gibbons,

8 So do not wait for autumn in the Chu hills.

\subsection{3}

Seeing Off Administrator Yang on His Way to Guozhou ${ }^{1}$

Baoye Valley is too narrow for your carriage; ${ }^{2}$

You're leaving, but where are you going?

Only a path for birds for a thousand li;

4 Gibbons cry all hours of the day.

A traveler sacrificing to the road god on the public bridge;

The temple to the Maiden in a mountain wood. ${ }^{3}$

After we part, we share the same bright moon;

8 You should listen to the cries of the cuckoo. ${ }^{4}$

\subsection{4}

Seeing off Xing of Guizhou ${ }^{5}$

Handbells and flutes resound in Jingkou; ${ }^{6}$

Windblown waves descend from Dongting.

1 See note to 7.33 .

2 Near Baocheng in Liangzhou, southwest of the capital (on the way to Shu).

3 The Maiden was worshipped near Baocheng (possibly associated with Daoist sects in Shu).

4 Whose cries supposedly sounded like the phrase, "Best to go home!"

5 In Guangxi.

6 Not too far from Yangzhou. 
赫折將赤岸,

4 魹汰復掦舲。

日落江湖白,

潮來天地青。

明珠歸合浦,

8 應逐使臣星。

\subsection{5}

送宇文三赴河西充行軍司馬

横吹雜繁笳,

邊風捲塞沙。

還聞田司馬,

4 更逐李輕車。

蒲類成秦地,

莎車屬漢家。

當令犬戎國,

8 朝聘學昆邪。 
Russet Boundary, and then Redbank; ${ }^{1}$

4 Striking the waves, your barque will spread its sails.

At sunset, rivers and lakes turn pale;

The tide comes in, Heaven and Earth darken.

Bright pearls will return to Hepu; ${ }^{2}$

8 And you should follow the emissary stars. ${ }^{3}$

\subsection{5}

Seeing off Yuwen Three to Hexi to take the post of adjutant ${ }^{4}$

Bamboo flutes combine with a profusion of barbarian reeds;

The border wind curls up the frontier sand.

I hear yet that Adjutant Tian

4 Will go off to follow Light Carriage Li. ${ }^{5}$

Pulei has now become Qin territory,

And Shaju subject to the house of Han. ${ }^{6}$

Force the countries of the Dog Rong

8 To pay us court in imitation of the Hunye! ${ }^{7}$

1 Both locations on the lower Jiang.

2 See note to 8.10.5. Xing will ensure the pearl trade in the region.

3 An astrologer recognized two emissaries sent to him from the court because he saw two stars enter the astrological counterpart of his district.

4 See note to 8.3 .

5 Two figures from Han military history. Light Carriage Li was the nickname of Li Cai 李蔡.

6 Both Han era nomad kingdoms, in places now located in eastern Xinjiang.

7 The Hunye were a tribe of Xiongnu (modern Gansu) that surrendered to the Han after its ruler was threatened by the Shanyu. 


\subsection{6}

送孫二

郊外誰相送,

夫君道術親。

書生㱀魚客,

4 才子洛陽人。 祖席依寒草, 行車起暮塺。 山川何叔寞,

8 長望淚露巾。

\subsection{7}

送崔三往密州唓省

南陌去悠悠, 東郊不少留。 同懷扇枕戀,

4 獨解倚門愁。 


\subsection{6}

\section{Seeing off Sun Two}

Beyond the outskirts, who will see you off?

You, a gentleman familiar with the Daoist arts, A scholar, a sojourner of Zou and $\mathrm{Lu},{ }^{1}$

4 A talent, a man of Luoyang. The parting banquet mat spread over cold grasses, The moving carriage stirs up the twilight dust.

How lonely and quiet the mountains and streams!

8 I gaze afar and the tears soak my kerchief.

\subsection{7}

Seeing off Cui Three on his way to Mizhou to see his parents ${ }^{2}$

On southern lanes you depart, moving on and on;

We can't detain you for a moment in the eastern suburbs.

With you I hold dear a fan-and-pillow affection; ${ }^{3}$

4 But you alone are able to relieve the grief of those who lean on the gate. ${ }^{4}$

1 Pre-imperial states associated with Confucian scholarship.

2 Mizhou: located on the southern coast of Shandong.

3 An outstanding act of filial piety: fanning the parents at their pillow and couch during the summer.

4 See note to 8.21.7. 


\section{路遶天山雪,}

家臨海樹秋。

鲁連功未報,

8 且莫蹈浛洲。

\subsection{8}

送邱為落第歸江東

憐君不得意,

況復柳條春。

為客黄金盡,

4 還家白髮新。

五湖三畮宅,

萬里一歸人。

知禰不能薦,

8 羞為獻納臣。

1 On the northwest frontier. This poem was probably composed when Wang Wei was serving in the northwest with Cui Xiyi.

$2 \mathrm{Lu}$ Zhonglian 魯仲連 was a famous orator of the Warring States period. He became a recluse (poetic, "tread on blue islet") rather than accept a fiefdom that would cause him to be subordinate to others.

3 The Jiang delta region. 
Your road circles the snow on Heaven Mountain; ${ }^{1}$

At home will meet autumn with its seaside trees.

Lu Zhonglian has yet to be rewarded for his achievements;

8 But for the time being, do not tread on some blue islet! ${ }^{2}$

\subsection{8}

Seeing off Qiu Wei upon his failing the examinations and returning to Jiangdong ${ }^{3}$

I feel for you, that you have been disappointed;

The more so in this season of willow branches. ${ }^{4}$

As a stranger here, you've spent all your gold; ${ }^{5}$

4 You return home, with hair just turned white.

To the Five Lakes, to your three-mou homestead,

You return, one man traveling ten thousand li.

I know that you're a Mi Heng, but could not recommend you;

8 I am ashamed that I'm a censorate official. ${ }^{6}$

4 Willow branches were presented to people departing, as a poetic wish that they might be detained ("willow" and "detain" are pronounced the same).

5 This echoes a phrase in Zhanguo ce about Su Qin's 蘇秦 attempt to attract the attention of the King of Qin with numerous letters, all of which were ignored. Soon he had spent all of his money in his efforts to be heard.

6 The third-century scholar Mi Heng 禰衡 was a young genius but also possessed of an unyielding personality. The older scholar Kong Rong 孔融 wrote a famous letter recommending him to Cao Cao when he was still a teenager. Wang is apologizing for not using his own position to further his friend's career. 


\subsection{9}

漢江臨汎

楚塞三湘接，

荆門九派通。

江流天地外,

4 山色有無中。 郡邑浮前浦, 波阇動遠空。 襄陽好風日，

8 留醉與山翁。

\subsection{0}

登辨覺寺

竹徑從初地, 蓮峰出化城。 窗中三楚盡, 4 林上九江平。 輭草承跃坐, 長松響梵聲。 空居法雲外,

8 觀世得無生。 


\subsection{9}

\section{Drifting on the Han River}

Chu borderlands - the Three Xiang Rivers meet;

Jingmen - the nine tributaries join.

The river flows beyond Heaven and Earth;

4 The mountain's color between being and nothingness.

The district boroughs float on the farther bank;

The river waves shake the distant sky.

Wonderful is Xiangyang's scenery -

8 I'll stay and get drunk with an old mountain man.

\subsection{0}

Climbing to the Monastery of Discerning Enlightenment ${ }^{1}$

The bamboo path links with the first stage of the bodhisattva's course; A city of illusion rises from Lotus Peak. ${ }^{2}$

From the window, the three lands of Chu stretch to their end;

4 Above the forest, the Nine Rivers level off.

Soft grasses accept seated meditators;

Tall pines echo with the sound of sutra chants.

I dwell in emptiness beyond the cloud of the Dharma,

8 Observe the world, obtain Non-rebirth.

1 The landscape described here suggests that the temple is located at Mount Lu in the central Yangtze valley.

2 City of illusion: in a parable from the Lotus Sutra, a guide conjures an imaginary city to bring comfort to some weary travelers; it serves as a metaphor for skillful means. Mount Lu had a Lotus Peak, though Wang Wei is also suggesting a place fit for preaching sutras as well. In general, the monastery becomes a place of wisdom and skillful means for the traveler set on becoming a bodhisattva. 


\subsection{1}

涼州郊外游望

野老才三戶，

邊村少四鄰。

婆乷依里社,

4 簫鼓賽田神。

灑酒澆㫚狗,

焚香拜木人。

女巫紛屡舞,

8 羅襙自生塵。

\subsection{2}

觀獵

風勁角弓鳴, 將軍獵渭城。 草枯鷹眼疾,

4 雪盡馬蹄輕。 忽過新豊市, 還歸細柳管。 回看射鵰處, 8 千里暮雲平。 


\subsection{1}

Gazing afar on the outskirts of Liangzhou ${ }^{1}$

Rustic old men, barely three households:

A border village with few neighbors.

Whirling, they head toward the village shrine;

4 With pipes and drums they sacrifice to the field god.

Sprinkling ale, they give libations to straw dogs;

Burn incense, bow before wooden effigies.

The shamanka dances a profusion of steps:

8 Dust rises from her silken stockings.

\subsection{2}

Observing the hunt

The wind is sharp; the horn-tipped bows ring out:

The general is hunting at Weicheng.

The grass is dry: the hawk's eye keen;

4 Snow has melted: the horses pace lightly.

Suddenly they pass Xinfeng Market, ${ }^{2}$

Then return to Slender Willow Camp. ${ }^{3}$

Turn back and look to where the hawk was shot:

8 For a thousand li, the evening clouds are level.

1 Composed 737-738 while in service with Cui Xiyi.

2 A town near the capital, famous for its ale.

3 A training camp near the capital during the Han dynasty, erected by the general Zhou Yafu 周亞夫. 